\title{
SOLID STATE SYNTHESIS AND CHARACTERIZATION OF PYRAZOLE AND PYRAZOLATES COMPLEXES OF COBALT (II) IONS
}

Abubakar, T., ${ }^{1 *}$ Kurawa, M. A., ${ }^{2}$ Isyaku, S. ${ }^{1}$ and Ozoro, E.C. ${ }^{3}$

1. Department of Chemistry, Faculty of Physical Sciences, Ahmadu Bello University, Zaria. ${ }^{1}$

2. Department of Pure and Industrial Chemistry, Bayero University, Kano. ${ }^{2}$

3. Crescent International School, Kano. ${ }^{3}$

${ }^{*}$ Corresponding Author: tukurabubakar19@gmail.com , 08037457119.

\section{ABSTRACT}

There were two ways used to synthesized cobalt (II) complexes of pyrazole by solid state. The first route involved direct reaction of the appropriate cobalt (II) acetate with pyrazole and pyrazolium chloride to form bispyrazole cobalt(II) salts, $\left[(\mathrm{HPz})_{2} \mathrm{CoCl}_{2}\right]$. This was further ground in the second route with a two equivalents of a base (KOH) to make polymeric cobalt (II) pyrazolate $\left[\mathrm{Co}(\mathrm{Pz})_{2}\right]$. In all the synthesis above the ratio of ligand to cobalt (II) acetate was 2:1. All the cobalt (II) complexes were found to be of different colour from the starting materials and were characterized using solubility test, which showed that the complexes have poor solubility in most of the solvents used except in dimethylsulfoxide where they were soluble and the molar conductivity measurements of the complexes have low values (ranging from $6.44-6.45 \Omega^{-1} \mathrm{~cm}^{2} \mathrm{~mol}^{1}$ ) which showed that they are non-electrolytes. The decomposition temperature showed that all the complexes have relatively low decomposition temperatures $\left(93^{\circ} \mathrm{C}-95^{\circ} \mathrm{C}\right)$. Characterization of the complexes via infrared analysis confirmed the coordination of metal with the ligand through pyridine-nitrogen and deprotonated-nitrogen in the range of $435.93 \mathrm{~cm}^{-1} \mathrm{Co}-\mathrm{N}$ bonds and $406.99 \mathrm{~cm}^{-1} \mathrm{Co}-\mathrm{N}$ (for the route $A$ and $B$ respectively). The magnetic susceptibility measurements were carried out at room temperature and the effective magnetic moment values for all the complexes further confirmed complexation of the metal (II) ions with the ligand and also indicates that the cobalt (II) complexes are paramagnetic. The plot of absorbance against mole fraction in each case gives a curve with maximum absorbance corresponding to the ligand mole fraction used in calculating the number of coordinated ligands and 1:2 metal-ligand ratios were obtained in all the complexes.

Keywords: Mechanochemical, Pyrazole, Pyrazolate, Grinding, Mechanochemical Elimination.

\section{INTRODUCTION}

Grinding is a general term describing mechanical action by hard surfaces on a material, normally to break up the material and reduce its particle size. It may therefore refer to manual methods (mortar and pestle) or non-manual methods such as ball milling. Very small amounts of added liquid can dramatically accelerate, and even enable mechanochemical reactions between solids (Chen et al., 1997). Often the molar equivalents added are similar to those of the reactants themselves. Such reactions are therefore 'minimal solvent' rather than strictly 'solvent-free' (Halcrow 2009). The term 'solventfree' synthesis is often accurate in a practical sense and care must be taken when making mechanistic interpretations. In the same general context, while a reaction in itself may be described as 'solvent-free' (in the practical and/or mechanistic sense), purification may still be needed and this may require a solvent. Therefore, a solvent-free reaction does not necessarily correspond to a solvent-free process overall (Angelici 1971 and Antesberger et al., 2005).

Pyrazole other name 1,2-Diazole is an organic compound with the formula $\mathrm{C}_{3} \mathrm{H}_{3} \mathrm{~N}_{2} \mathrm{H}$. It is a heterocycle characterized by a 5 -membered ring of three carbon atoms and two adjacent nitrogen atoms. Pyrazole is a weak base, with $\mathrm{p} K_{\mathrm{b}} 11.5$ ( $\mathrm{p} K_{\mathrm{a}}$ of the conjugated acid 2.49 at $25^{\circ} \mathrm{C}$ ). Pyrazoles are also a class of compounds that have the ring $\mathrm{C}_{3} \mathrm{~N}_{2}$ with adjacent nitrogen atoms (Balema et al., 2002). A notable drug containing a pyrazole ring is celecoxib (Celebrex) (Retting et al., 1991). 
Special Conference Edition, November, 2019

Pyrazole ( $\mathrm{HPz})$ is a well-known monodentate ligand, coordinating via the pyridine nitrogen of the ring. Because HPz is a weak acid ( $\mathrm{pK}=14$ ), it is also possible to obtain metal compounds with the pyrazolato ion ( $\mathrm{Pz}^{-}$) (Groeneveld et al., 1976 and Sindhu et al., 2013).

\section{MATERIALS AND METHODS}

All the chemicals and reagents were of analytical grade and used as received without further purifications.

\section{Synthesis}

Two synthetic routes were used and carried out at room temperature using standard glassware. The glass wares were washed and dried in an oven before the start of each synthesis.

The metal salts $\mathrm{Co}\left(\mathrm{CH}_{3} \mathrm{COO}\right)_{2}$ and the ligands in each case were ground by hand using a mortar and pestle to give the desired products. The time required in grinding was mostly 3 minutes which is typically only that necessary to be sure that all the reactants have been thoroughly mixed in each case. The reactants in each case were weighed using electric balance in the laboratory. In all the synthesis the ratio of the ligand to metal salts was 2:1. The Products were dried in oven at $50^{\circ} \mathrm{C}$ (Adams et al., 2008 and 2010).

\section{A: synthesis using Pyrazole $\left(\mathrm{C}_{3} \mathrm{H}_{4} \mathrm{~N}_{2}\right)$ as} ligand

Route A: Direct grinding of $\mathrm{M}\left(\mathrm{CH}_{3} \mathrm{COO}\right)_{2}$ with neutral pyrazole to form coordination compound $\left[\mathrm{M}(\mathrm{Pz})_{2}\right]$

$$
\mathrm{M}\left(\mathrm{CH}_{3} \mathrm{COO}_{2}+\right.
$$

Scheme 1: Synthesis of coordination compound by direct grinding of pyrazole and metal (II) salts. [M = Co].

\section{Synthesis of Cobalt pyrazolate Complex, $\left[\mathrm{Co}(\mathbf{P z})_{2}\right]$ :}

$249 \mathrm{mg}(1 \mathrm{mmol})$ of $\left(\mathrm{CH}_{3} \mathrm{COO}\right)_{2} \mathrm{Co} .4 \mathrm{H}_{2} \mathrm{O}$ and $136 \mathrm{mg}(2 \mathrm{mmol})$ of white crystalline pyrazole were mixed and grinded, resulting in the formation of a green powder and dried in an oven at $50^{\circ} \mathrm{C}$ to evaporate the acetic acid, (Adams et al., 2010).

\section{B: Synthesis Using Pyrazolium Chloride, $\left[\mathrm{H}_{2} \mathrm{Pz}\right] \mathrm{Cl}$}

Pyrazolium Chloride, $\left[\mathrm{H}_{2} \mathrm{Pz}\right] \mathrm{Cl}$ a beaker containing some amount of pyrazole was placed in a sealed desiccators, containing some quantity of concentrated hydrochloric acid, $\mathrm{HCl}$. The hydrogen chloride gas $\left(\mathrm{HCl}_{(\mathrm{g})}\right)$ produced from $\mathrm{HCl}$ acid was directly entered in to the beaker containing the white crystalline pyrazole continuously for 7hours. The white crystals instantaneously become a cream-coloured powder which is the pyrazolium chloride, $\left[\mathrm{H}_{2} \mathrm{Pz}\right] \mathrm{Cl}$ (Adams et al., 2008 and 2010).

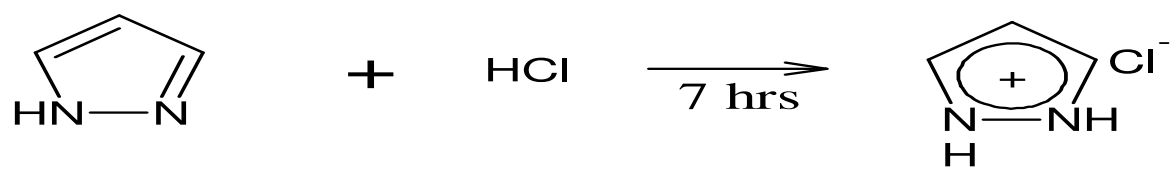

Pyrazole

Pyrazolium Chloride

\section{Scheme 2: Synthesis of pyrazolium chloride}

$209 \mathrm{mg}(2 \mathrm{mmol})$ of pyrazolium chloride, $\left[\mathrm{H}_{2} \mathrm{Pz}\right] \mathrm{Cl}$ was grinded with $1 \mathrm{mmol}$ of the metal acetates, $\mathrm{Co}\left(\mathrm{CH}_{3} \mathrm{COO}\right)_{2} .4 \mathrm{H}_{2} \mathrm{O}$. In all the ratio of the ligand to metal salts was 2:1 to give a general form as $\left[\mathrm{CoCl}_{2}(\mathrm{HPz})_{2}\right]+$ acetic acid given off on drying in an oven at $50^{\circ} \mathrm{C}$, (Adams et al., 2008 and 2010).

$$
\begin{gathered}
\mathrm{Co}\left(\mathrm{CH}_{3} \mathrm{COO}\right)_{2} \\
{\left[\mathrm{COCl}_{2}(\mathrm{HPz})_{2}\right]} \\
1
\end{gathered}+\underset{2}{2 \mathrm{CH}_{3} \mathrm{COOH} \uparrow}+\underset{2}{:}
$$

Mechanochemical Elimination:

This method was used to eliminate the chloride in $\left[\mathrm{MCl}_{2}(\mathrm{HPz})_{2}\right]$ using $\mathrm{KOH}_{(\mathrm{s})}$ and metal pyrazolates, $\left[\mathrm{M}(\mathrm{Pz})_{2}\right]+2 \mathrm{KCl}+2 \mathrm{H}_{2} \mathrm{O}$ were obtained. 
Special Conference Edition, November, 2019

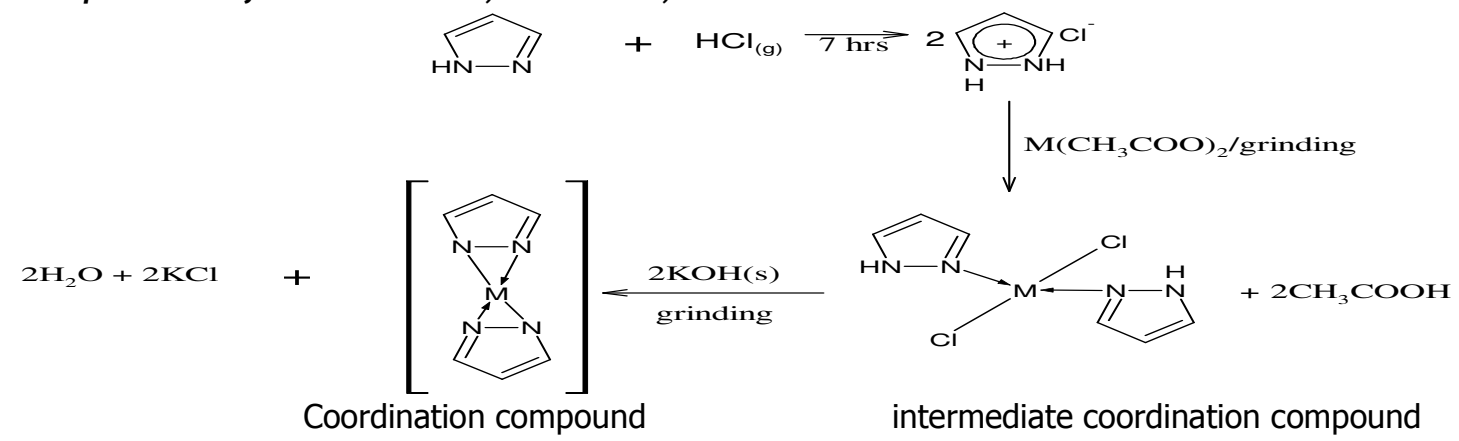

Scheme 3: Synthesis of coordination compound using pyrazolium chloride, $[M=C o]$.

\begin{abstract}
3.3.3.3 Synthesis of Cobalt pyrazolate Complex, $\left[\mathrm{Co}(\mathrm{Pz})_{2}\right.$

$249 \mathrm{mg}(1 \mathrm{mmol})$ of $\left(\mathrm{CH}_{3} \mathrm{COO}\right)_{2} \quad \mathrm{Co} .4 \mathrm{H}_{2} \mathrm{O}$ and $209 \mathrm{mg}(2 \mathrm{mmol})$ of cream-coloured pyrazolium chloride were mixed and grinded, resulting in the formation of a dark green polycrystalline powder $\left[\mathrm{CoCl}_{2}(\mathrm{HPz})_{2}\right]$ and dried in an oven to evaporate the acetic acid, (Adams et al., 2008 and 2010).
\end{abstract}

\title{
RESULTS AND DISCUSSION
}

The results of the mechanochemical synthesis carried out above are shown in the tables below.

Table1a: Solubility test of the Ligand and Co(II) Complex obtained by Route A in some Common Solvents:

\begin{tabular}{lllllllllll}
$\begin{array}{l}\text { Solvents/L } \\
\text { /Complexe } \\
\text { s }\end{array}$ & $\begin{array}{l}\text { Dist. } \\
\mathbf{H}_{\mathbf{2}} \mathbf{O}\end{array}$ & Ethanol & Methanol & $\mathbf{C C l}_{\mathbf{4}}$ & $\mathbf{C H C l}_{\mathbf{3}}$ & Ether & $\mathbf{C}_{\mathbf{6}} \mathbf{H}_{\mathbf{6}}$ & $\begin{array}{l}\mathbf{n}- \\
\text { Hexane }\end{array}$ & Acetone DMSO \\
\hline$[\mathrm{HPz}]$ & $\mathrm{S}$ & $\mathrm{S}$ & $\mathrm{S}$ & $\mathrm{S}$ & $\mathrm{S}$ & $\mathrm{S}$ & $\mathrm{S}$ & $\mathrm{S}$ & $\mathrm{S}$ & $\mathrm{S}$ \\
{$\left[\mathrm{CO}(\mathrm{Pz})_{2}\right]$} & $\mathrm{SS}$ & $\mathrm{SS}$ & $\mathrm{SS}$ & $\mathrm{IS}$ & IS & IS & IS & IS & IS & $\mathrm{S}$ \\
\hline
\end{tabular}

Table1b: Solubility test of the Ligand and Co (II) Complex obtained by Route B in some Common Solvents:

\begin{tabular}{|c|c|c|c|c|c|c|c|c|c|c|c|}
\hline $\begin{array}{l}\text { Solvents/L } \\
\text { /Complexe } \\
\text { s }\end{array}$ & $\begin{array}{l}\text { Dist. } \\
\mathrm{H}_{2} \mathrm{O}\end{array}$ & Ethanol & Methanol & $\mathrm{CCl}_{4}$ & $\mathrm{CHCl}_{3}$ & Ether & $\mathrm{C}_{6} \mathrm{H}_{6}$ & $\begin{array}{l}\text { n- } \\
\text { Hex }\end{array}$ & ane & $\begin{array}{l}\text { Aceto } \\
\text { nes }\end{array}$ & DMSO \\
\hline$\left[\mathrm{H}_{2} \mathrm{Pz}\right] \mathrm{Cl}$ & $S$ & $S$ & $S$ & $S$ & $S$ & $S$ & $S$ & & $\mathrm{~S}$ & $S$ & $S$ \\
\hline$\left[\mathrm{Co}(\mathrm{Pz})_{2}\right]$ & SS & IS & IS & SS & SS & IS & IS & IS & & IS & $\mathrm{S}$ \\
\hline $\begin{array}{r}S=S \\
\text { Table2a: }\end{array}$ & $\begin{array}{l}\text { OLUBLE } \\
\text { lolecul } \\
\text { gand ( }\end{array}$ & $\begin{array}{r}\mathrm{SS} \\
\text { mass, } \\
\text { razole) a }\end{array}$ & $\begin{array}{l}=\text { SLIGHTL } \\
\text { nelting pc } \\
\text { nd the syn }\end{array}$ & $\begin{array}{l}\text { SOLUE } \\
\text { int/de } \\
\text { hesize }\end{array}$ & $\begin{array}{l}\mathrm{LE} \quad \mathrm{A} \\
\text { omposi } \\
\text { I compl }\end{array}$ & $\begin{array}{l}\text { ND } \\
\text { ition t } \\
\text { exobta }\end{array}$ & $\begin{array}{c}\text { IS = } \\
\text { emper } \\
\text { ined b }\end{array}$ & $\begin{array}{l}=\text { INSC } \\
\text { ratur } \\
\text { by Ro }\end{array}$ & $\begin{array}{l}\text { LUUB } \\
\text { e, c } \\
\text { ute }\end{array}$ & urs & the \\
\hline \multicolumn{2}{|c|}{ Ligand/complexes } & $\begin{array}{l}\text { Molecular } \\
(\mathrm{g} / \mathrm{mol})\end{array}$ & mass $M$ & ting $\mathrm{pc}$ & int $\left({ }^{\circ} \mathrm{C}\right)$ & \multicolumn{3}{|c|}{$\begin{array}{l}\text { Decomposition } \\
\text { Temp. }\left({ }^{\circ} \mathrm{C}\right)\end{array}$} & \multicolumn{2}{|c|}{ Colour } & \\
\hline \multicolumn{2}{|l|}{$\mathrm{C}_{3} \mathrm{H}_{4} \mathrm{~N}_{2}$} & 68.08 & & 70 & & \multicolumn{2}{|c|}{-} & \multicolumn{3}{|c|}{$\begin{array}{l}\text { White } \\
\text { crystals }\end{array}$} & \\
\hline \multicolumn{2}{|c|}{$\left[\mathrm{Co}\left(\mathrm{C}_{3} \mathrm{H}_{3} \mathrm{~N}_{2}\right)_{2}\right]$} & 193.00 & & - & & \multicolumn{2}{|c|}{93} & \multicolumn{3}{|c|}{ Dark Green } & \\
\hline
\end{tabular}

Table2b: Molecular mass, melting point/decomposition temperature, colours of the ligand (Pyrazolium Chloride) and the synthesized complex obtained by Route B.

\begin{tabular}{|c|c|c|c|c|c|}
\hline Ligand/complexes & $\begin{array}{l}\text { Molecular } \\
\text { (g/mol) }\end{array}$ & mass & $\begin{array}{l}\text { Melting point } \\
\left({ }^{\circ} \mathrm{C}\right)\end{array}$ & $\begin{array}{l}\text { Decomposition } \\
\text { Temp }\left({ }^{\circ} \mathrm{C}\right)\end{array}$ & Colour \\
\hline $\begin{array}{l}{\left[\mathrm{C}_{3} \mathrm{H}_{5} \mathrm{~N}_{2}\right] \mathrm{Cl}} \\
{\left[\mathrm{Co}\left(\mathrm{C}_{3} \mathrm{H}_{3} \mathrm{~N}_{2}\right)_{2}\right]}\end{array}$ & $\begin{array}{c}104.58 \\
193.00\end{array}$ & & $\begin{array}{l}75 \\
-\end{array}$ & 95 & $\begin{array}{l}\text { Cream Powder } \\
\text { Pale -Brown }\end{array}$ \\
\hline
\end{tabular}


Special Conference Edition, November, 2019

Table 3a: Conductivity Measurement for the Co (II) Complexobtained by Route A

Complex

Specific Conductance

$\left(\Omega^{-1} \mathrm{~cm}^{-1}\right)$

Molar Conductance

$\left(\Omega^{-1} \mathrm{~cm}^{2} \mathrm{~mol}^{-1}\right)$

$\begin{array}{lll}\left.\mathrm{Co}(\mathrm{Pz})_{2}\right] & 6.44 \times 10^{-6} & 6.44\end{array}$

Table 3b: Conductivity Measurement for the Co (II) Complex obtained by Route B

Complex Specific Conductance

$\left(\Omega^{-1} \mathrm{~cm}^{-1}\right)$
Molar Conductance

$\left(\Omega^{-1} \mathrm{~cm}^{2} \mathrm{~mol}^{-1}\right)$

\begin{tabular}{lll}
\hline$\left[\mathrm{Co}(\mathrm{Pz})_{2}\right]$ & $6.45 \times 10^{-6}$ & 6.45
\end{tabular}

Table4a: Magnetic Susceptibility Measurement for Co (II) acetates

\begin{tabular}{llllll}
\hline Metal(II) & Gram Magnetic & Molar magnetic & meffective in Bohr & Properties \\
acetates & Susceptibility $x_{\mathrm{g}}$ & Susceptibility $x_{\mathrm{m}}$ & Magnetons, (B.M) &
\end{tabular}

$\begin{array}{lllll}\left(\mathrm{CH}_{3} \mathrm{COO}\right)_{2} \mathrm{Co} & 2.24 \times 10^{-5} & 5.58 \times 10^{-3} & 3.65 & \text { Paramagnetic }\end{array}$

Table 4b: Magnetic Susceptibility Measurement for Co(II) Complexes obtained by Route A

Complexes Gram Magnetic Molar magnetic $\mu$ effective in Bohr Properties Susceptibility $x_{\mathrm{g}} \quad$ Susceptibility $x_{\mathrm{m}} \quad$ Magnetons, (B.M)

$\left[\begin{array}{llll}\left.\mathrm{Co}\left(\mathrm{C}_{3} \mathrm{H}_{3} \mathrm{~N}_{2}\right)_{2}\right] & 1.88 \times 10^{-5} & 3.62 \times 10^{-3} & 2.94\end{array}\right.$

Table4c: Magnetic Susceptibility Measurement for Co (II) Complexes obtained by Route B.

Complexes Gram Magnetic Molar magnetic $\mu$ effective in Bohr Properties Susceptibility $x_{\mathrm{g}} \quad$ Susceptibility $x_{\mathrm{m}} \quad$ Magnetons, (B.M)

\begin{tabular}{lllll}
{$\left[\mathrm{Co}\left(\mathrm{C}_{3} \mathrm{H}_{3} \mathrm{~N}_{2}\right)_{2}\right.$} & $1.91 \times 10^{-5}$ & $3.69 \times 10^{-3}$ & 2.96 & Paramagnetic \\
\hline
\end{tabular}

Table5a: Selected characteristic IR bands for Ligand and the Co(II) Complexes obtained by Route A.

\begin{tabular}{lcc}
\hline Complex & $\mathrm{v}(\mathrm{C}-\mathrm{N}) \mathrm{cm}^{-1}$ & $\mathrm{v}(\mathrm{M}-\mathrm{N}) \mathrm{cm}^{-1}$ \\
\hline $\mathrm{C}_{3} \mathrm{H}_{4} \mathrm{~N}_{2}$ & 1646.30 & - \\
{$\left[\mathrm{Co}\left(\mathrm{C}_{3} \mathrm{H}_{3} \mathrm{~N}_{2}\right)_{2}\right]$} & 1619.29 & 435.93 \\
\hline
\end{tabular}

Table5b: Selected characteristic IR bands for Ligand and the Co(II) Complexes obtained by Route $B$.

\begin{tabular}{lcc}
\hline Complex & $\mathrm{v}(\mathrm{C}-\mathrm{N}) \mathrm{cm}^{-1}$ & $\mathrm{v}(\mathrm{M}-\mathrm{N}) \mathrm{cm}^{-1}$ \\
\hline $\mathrm{C}_{3} \mathrm{H}_{4} \mathrm{~N}_{2}$ & 1646.30 & - \\
{$\left[\mathrm{Co}\left(\mathrm{C}_{3} \mathrm{H}_{3} \mathrm{~N}_{2}\right)_{2}\right]$} & 1596.15 & 406.99 \\
\hline
\end{tabular}

Table 6: Mole fraction of the ligand and absorbance values for $\mathrm{Co}^{2+}$ ion: $\lambda_{\max }=400 \mathrm{~nm}$

\begin{tabular}{lll}
\hline Co $: \mathbf{L}$ & L mole fraction & Absorbance \\
\hline $15: 01$ & 0.0625 & 0.1908 \\
$13: 03$ & 0.1875 & 0.1864 \\
$11: 05$ & 0.3125 & 0.3012 \\
$09: 07$ & 0.4375 & 0.3112 \\
$07: 09$ & 0.5625 & 0.3401 \\
$05: 11$ & 0.6875 & 0.3861 \\
$03: 13$ & 0.8125 & 0.3543 \\
$01: 15$ & 0.9375 & 0.2343 \\
$00: 16$ & 1.0000 & 0.2132 \\
\hline
\end{tabular}


Special Conference Edition, November, 2019 DISCUSSION

Pyrazole was deprotonated to give pyrazolate anion $\left(\mathrm{Pz}^{-}\right)$which function as a ligand and reacted with metal ion $\left(\mathrm{Co}^{2+}\right)$ to form coordination compounds $\left[\mathrm{Co}(\mathrm{Pz})_{2}\right]$. The proton combined with acetate ion (OAC) and give acetic acid (HOAC) (Mamatha et al., 2006).

Cobalt (II) pyrazolate complex was found to be insoluble in ethanol, carbon tetrachloride, chloroform, ether, benzene, n-hexane, distilled water, and acetone, slightly soluble in methanol and soluble in DMSO solvents (Flook et al., 1973) (Tables 1a and 1b). The melting point of pyrazole and the decomposition temperature of metal complexes were determined using microprocessor melting point apparatus (WRSIB) and Gallenkamp melting point apparatus. The results obtained showed that the complex which is dark-green with pyrazole and palebrown with pyrazolium salt has decomposition temperatures of $93^{\circ} \mathrm{C}$ and $95^{\circ} \mathrm{C}$ (Tables 2a and 2b). (Kumar and Pareek, 2013).

The molar conductivity measurements revealed that the complex have low values $\left(6.44-6.45 \Omega^{-}\right.$
${ }^{1} \mathrm{~cm}^{2} \mathrm{~mol}^{-1}$ ) which showed that they are nonelectrolytes.

The magnetic susceptibility measurements were carried out at room temperature and the effective magnetic moment values for Co (II) complexes obtained are within characteristic of mononuclear, Co (II) (d $\left.d^{7}\right)$ indicating paramagnetic nature (Seel and Sperber 1968; Lancashire 2015).

In the low-frequency region, the spectra of the metal complexes exhibited new bands which are not present in the spectrum of the ligand and cobalt (II) acetate ${ }^{17}$. These bands assigned to $\mathrm{v}(\mathrm{M}-\mathrm{N})$ vibrations observed at $435.93 \mathrm{~cm}^{-1}$ and $406.99 \mathrm{~cm}^{-1}$ for Cobalt, (Maurya 2004 and Raman et al., 2010) (Tables 5a and 5b). The plot of absorbance against mole fraction gives a curve with maximum absorbance corresponding to the ligand mole fraction used in calculating the number of coordinated ligand and 1:2 metalligand ratios was obtained in all the complexes (Alan 2009 and Bahl, 2007) (Table 6).

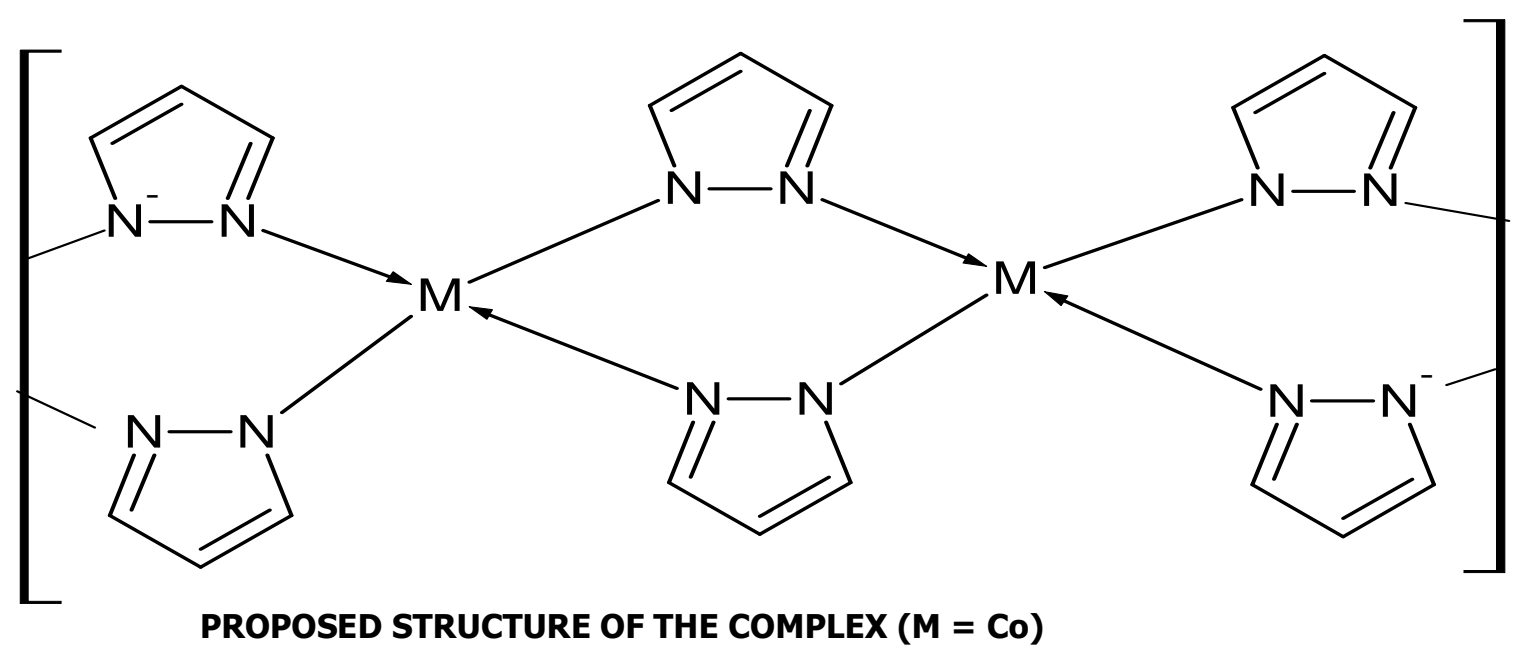

\section{REFERENCES}

Adams C. J., Kurawa M. A. and Orpen A. G., (2010). Coordination chemistry in the solid state: synthesis and interconversion of pyrazolium salts, pyrazole complexes, and pyrazolate MOFs. J. Royal Society of Chemistry. Dalton Trans., 39:6974-6984.

Adams C. J., Kurawa M. A., Lusi M. and Orpen A. G.,(2008). Solid State synthesis of coordination compounds from basic metal salts.Cryst. EngComm., 10:17901795

Adams C. J., Haddow M. F., Hughes R. J. I., Kurawa M. A., and Orpen A. G., (2010).Coordination chemistry of platinum and palladium in the solid- state: Synthesis of imidazole and pyrazole complexes.39:3714-3724.

Alan L. Balch, (2009). Solid state synthesis of coordination compounds from basic metal salt.J. Angew. Chem.,Int. Ed., 48:2641-2644.

Angelici, R.J. (1971). "Synthesis and Techniques in Inorganic Chemistry", W. B. Savders Company, Dalton Trans. $2^{\text {nd }}$ Edition, pp 115-125.

Antesberger J., G. W. V. Cave, M. C. Ferrarelli, M. W. Heaven, C. L. Raston and J. L. Atwood, (2005). Solvent-free, direct synthesis of supramolecular nanocapsules. Chem. Commun., 892-894.

Bahl A. and Bahl B. S. (2007). Advanced Organic Chemistry, S. Cand and Company Ltd, 
Special Conference Edition, November, 2019

Ram Nagar, New Delhi, $20^{\text {th }}$ edition, pp $490-497$.

Balema V. P., J. W. Wiench, M. Pruski and V. K. Pecharsky,(2002). Mechanochemically induced solid state generation of phosphorus ylides and the solvent-free witting reaction. Chem. Commun. Cambridge, Pp 45-47.

Chen T., B. Liang and X. Xin, (1997). Studies on Solid-Solid Reactions between 4Methylbenzenamine and Copper (II)Chloridedihydrate, Cobalt (II)Chloridehexahydrate and Nickel (II) Chloridehexahydrate. J. Solid State Chem.132(2):291-293.

Flook R. J., Freeman H. C., Huq F. and Rosalky J. M., (1973). Stereochemistry of Cobalt porphyrins. ActaCrystallogr., Sect. A: Cryst. Phys., Diffr., Theor. Gen. Crystallogr., B 29, 903.

Groeneveld W.L, Okkersen H., and Reedijk J., (1976). Pyrazolato and related anions, salt of 4-nitropyrazole.Rec. Trav. Chim., 92:947.

Halcrow M. A., (2009). Pyrazole and pyrazolidesflexible synthons in self. In Heterocyclic chemistry. J. Dalton Trans.,2059 - 2073.

Kumar N. Sharma and Pareek A. (2013), synthesis of new Schiff base complexes and their applications. International Journal of Applied Research and Studies II (2):307-315.

Kuroda R., Yoshida J., Nakamura A. and Nishikiori S.I., (2009). Annealing assisted mechanochemical synthesis of transition-metal coordination compounds and co-crystal formation. J. Cryst. Eng. Comm., 11:427 - 432 .

Lancashire R.J., (2015), Coordination Chemistry. Kingston, Jamaica. Available on www.chem.uwimona.edu.jm/spectra/Ma g Mon.html.
Mamatha M., Bogdanovic,B., Felderho,M., Pommerin,A., Schmidt,W. Schuth, F. and Weidenthaler,C. (2006). Mechanochemical preparation and investigation of properties of magnesium, calcium and lithiummagnesium alanates. J. Alloys Compd., 407:78-86.

Maurya R. C. and Rajput S., (2004), Oxovanadium (IV) complexes of bioinorganic and medicinal relevance: synthesis, characterization and 3D molecular modeling and analysis of some oxovanadium (IV) complexes involving O, O-donor environment, J. Mol. Struct. 687(1): 35-44.

Raman N., Jeyamurugan R., Rajkapoor, B. and Mitu, L. (2010). Novel metal- based pharmacologically dynamic agents of transition metal (II) complexes: Designing, synthesis, structural elucidation, DNA binding and photoinduced DNA cleavage: activity, Spectrochim. Acta, Part A 75(1):88-97.

Rettig S. J., Storr A. and Trotter J., (1991). Metal pyrazolate polymers: synthesis, structure and magnetic properties of copper (II) pyrazolate polymers. Can. J. Chem., 69:432.

See1 F., and Sperber V., (1968). Interpretation of NMR chemical shifts and magnetic susceptibilities. J. Angew. Chem., 80:38.

Sindhu Y., Athira C.J., Sujamol M. S., Selwin R.J. and Mohanan K., (2013). Synthesis, characterization, DNA cleavage, and antimicrobial studies of some transition metal complexes with a novel Schiff base derived from 2-aminopyrimidine, Synth. React. Inorg. Met-Org. Nano-Met. Chem. 43(3):226-23.

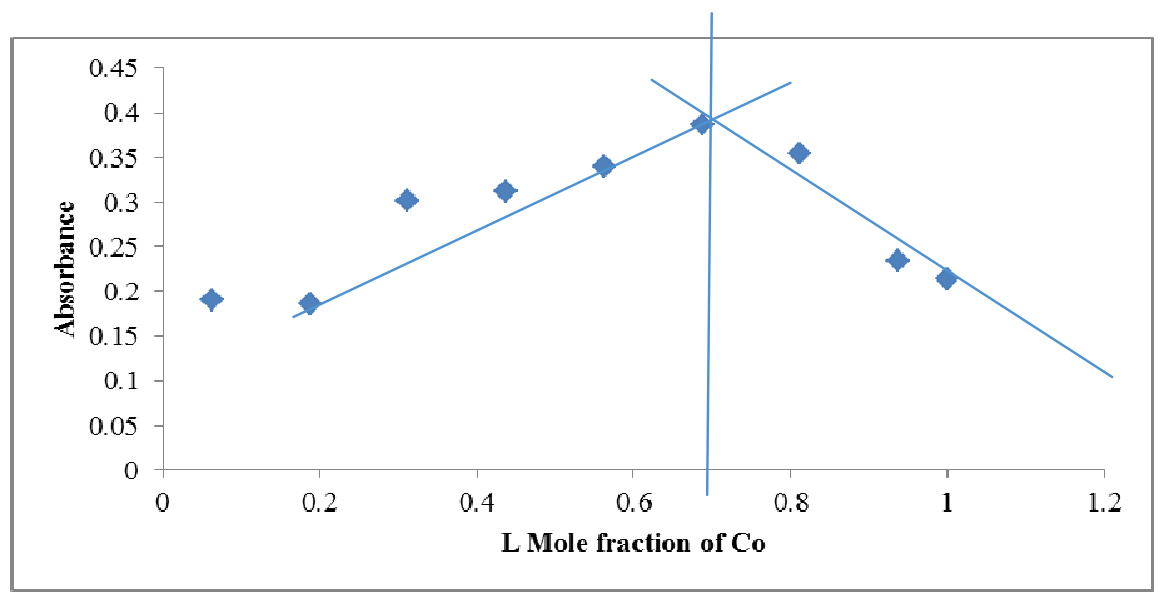

Plot of Absorbance against Ligand Mole Fraction for $\mathrm{Co}^{2+}$ ion: $\lambda_{\max }=400 \mathrm{~nm}$ 
FTIR ANALYSIS RESULT

NATICNAL REASEARCH INSTITUTE FOR OHENCAL TECHNCLOGY, ZLRLA
ФSHIMADZU

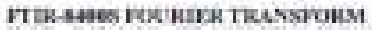

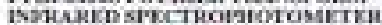

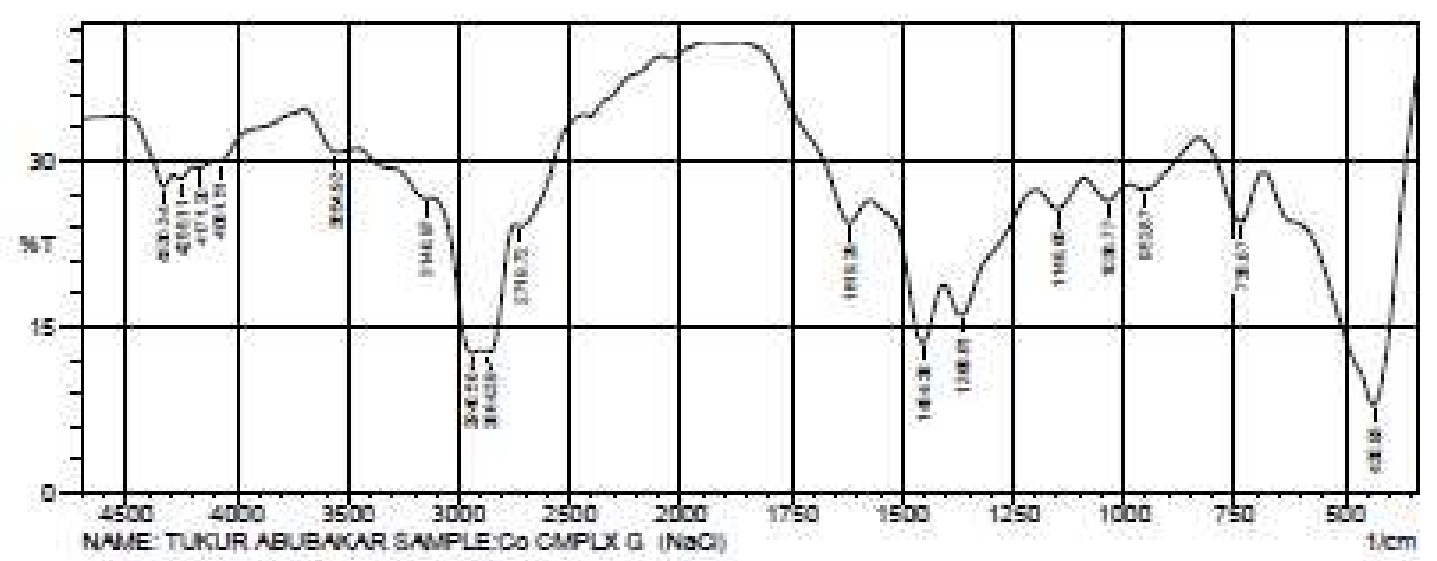

\begin{tabular}{|c|c|c|c|c|c|c|c|}
\hline 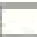 & Wear & inhemanty. & Cort, Mansity & Base (n) & Habe (ㄴ) & Area & Cort. Avera \\
\hline 7 & 4.562 & 8.05 & 2421 & $62 \%$ & 10.50 .45 & 205.15 & 27.83 \\
\hline 2 & $7358 ?$ & 2440 & 5.57 & $\cos 20$ & 66572 & $\pi 77$ & $5 \leqslant 2$ \\
\hline 2 & $052 \&$ ? & 274 & 139 & 0075 & 85036 & 6412 & 1.21 \\
\hline 4 & 100367 & 284 & 1.79 & 1087 ab & 06855 & sede & $1.2 x$ \\
\hline 2 & 114502 & 2568 & 278 & 17ved & 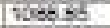 & Iteog & $11.4 \%$ \\
\hline e & 1986.61 & 1602 & 4.49 & 1406,35 & 1100.7e & 192057 & C.60 \\
\hline 7 & 545438 & 13.45 & 752 & 157204 & 1407.12 & 19509. & 2.10 \\
\hline$a$ & 185020 & 24.42 & 425 & 106428 & 1573 & 14393 & 404 \\
\hline 5 & 271022 & 24.11 & 620 & $27<28 ?$ & 1244009 & 164.97 & 284 \\
\hline 90 & 260432 & 127 & 2.59 & 2997.18 & 234353 & 11072 & 53 \\
\hline 11 & 204658 & $12 \mathrm{es}$ & 2.87 & 811 & 2608.14 & 163.18 & 5.46 \\
\hline 12 & 3143.97 & 2058 & 6.41 & 345655 & 31s00e & $\tan 10^{2}$ & 68 \\
\hline 13 & 355452 & 308 & 1.80 & 300477 & 1345752 & 17250 & 3.06 \\
\hline 14 & 4001.51 & 2906 & 0.72 & averot & $30 / 672$ & Tि5 \&? & 0.13 \\
\hline 15 & 41712 & $2036^{\circ}$ & 322 & $\operatorname{Ain} 28$ & 40065 & $5 x d t$ & 615 \\
\hline 36 & $4: 55.75$ & 2497 & 2058 & सख्येट & $418 \% 24$ & Edit & 035 \\
\hline तT & 4538.54 & $27=5$ & $2 \pi$ & este 4? & 4.0501: & fingy: & 730 \\
\hline
\end{tabular}

Ne. of Seans; 10

Date Time: $9: 8 / 200325807$ AM

Apodimation, Happ-Gennel

Revolution: 20 